Western University

Scholarship@Western

Biology Publications

Biology Department

$4-2013$

\title{
Does the Response of Insect Herbivores to Cadmium Depend on Their Feeding Strategy?
}

Joanna K. Konopka

Kazushi Hanyu

Sheila Macfie

smacfie@uwo.ca

Jeremy N. McNeil

Follow this and additional works at: https://ir.lib.uwo.ca/biologypub

Part of the Biology Commons

Citation of this paper:

Konopka, Joanna K.; Hanyu, Kazushi; Macfie, Sheila; and McNeil, Jeremy N., "Does the Response of Insect Herbivores to Cadmium Depend on Their Feeding Strategy?" (2013). Biology Publications. 45.

https://ir.lib.uwo.ca/biologypub/45 


\title{
DOES THE RESPONSE OF INSECT HERBIVORES TO CADMIUM DEPEND ON THEIR FEEDING STRATEGY?
}

\author{
JOANNA K. KONOPKA ${ }^{1}$, KAZUSHI HANYU ${ }^{2}$, SHEILA M. MACFIE ${ }^{1}$, AND JEREMY N. \\ $\mathrm{McNEIL}^{1 *}$ \\ ${ }^{I}$ Department of Biology, The University of Western Ontario, 1151 Richmond St. London, ON, N6A 5B7 Canada \\ ${ }^{2}$ Institute of Agriculture and Forestry, University of Tsukuba, Tsukuba, Japan \\ * corresponding author email: jmcneil2@uwo.ca; phone: 5196613487
}

\begin{abstract}
Phytoremediation has been proposed for the elimination of toxic metals in soil, yet little attention was given to the performance of insects that feed on contaminant-tolerant plants. We tested the performance of two herbivores with different feeding behaviors, the cabbage looper, Trichoplusia ni, and the green peach aphid, Myzus persicae, when reared on cadmium-tolerant Brassica juncea plants that contained different concentrations of cadmium. We also tested the performance of the aphid parasitoid Aphidius colmani developing in aphids reared on

17 plants with different levels of cadmium. The hypothesis tested was the chewing insect would be more negatively affected than the sucking insect due to the localization of cadmium within the host plant, and that the aphid parasitoid would not be affected. We also compared the performance of $T . n i$ on artificial diet with different levels of cadmium. Neither the phloem-feeding aphid nor its parasitoid was affected by cadmium in the host plant. In contrast literature, would support the idea that the effects of toxic metals present in a host plant will be influenced by the herbivore's feeding strategy. However, a wide range of chewing and sucking species need to be tested to confirm this hypothesis.
\end{abstract}

Key words- Cadmium, phytoremediation, feeding strategy, oviposition, Myzus persicae, Trichoplusia ni, Aphidius

9

0

1

2


High concentrations of metals in soils, originating from either natural or anthropogenic sources, may cause serious ecological problems due to their adverse effects on living organisms. Most current methods used for remediation of metal-contaminated soils are expensive and laborious, so there is an increasing interest in finding cheaper and more efficient means of improving soil quality. Phytoremediation, the use of plants to remove or chelate metals into less toxic forms, is a promising and cost effective method (Chaney et al., 1997; Cunningham et al., 1997). are unaffected by the high concentrations of various contaminants that accumulate in their roots and shoots (Kumar et al., 1995; Jahangir et al., 2008). However, when these metals are incorporated into plant tissues they may be biotransferred up the food chain, with a potential of impacting species at higher trophic levels (Hanson et al., 2003; Boyd, 2004) and affecting tritrophic interactions (Butler and Trumble, 2008). While a few studies reported a positive effect of metals such as copper (Filser et al., 2000) or iron (Bahadorani and Hilliker, 2009) on the behavior of insect herbivores (feeding, taxis, and oviposition), generally, if an effect is discernable it is negative (Butler and Trumble, 2008; Mogren and Trumble, 2010 and references therein).

Effects observed will not only depend on both the type of metal and the concentrations found in different parts of the plant but also on the insect species that is exposed. For example, herbivores with chewing mouthparts that feed on leaves may be exposed to different levels of the metal than those with sucking mouthparts feeding in the 51 vascular system. Furthermore, within a given species of herbivore it is important to consider how an individual 52 could be exposed during different stages of the life cycle. For example, if a female can distinguish between plants 53 with high and low concentrations of metals and avoid ovipositing on those with high levels, this would significantly 54 reduce the probability of her offspring being exposed. Similarly, if during feeding larvae are able to detect high 55 concentrations of metals, they could exhibit avoidance behavior and feed at more palatable sites. Cadmium (Cd) metal is extremely toxic to both plants and animals, including humans (Nordberg, 2009).

57 The Brassicaceae family contains the most Cd-tolerant plant species (Prasad, 1995), and B. juncea (Indian mustard), 58 has considerable potential for phytoremediation in soils with high concentrations of Cd (Kumar et al., 1995; Cui and 59 Chen, 2011). We used this host plant to examine the impact of $\mathrm{Cd}$ on two herbivorous pests with different feeding 60 strategies, testing the hypothesis that the foliage-feeding cabbage looper, Trichoplusia ni, would be affected 
61 significantly more than phloem-feeding green peach aphid, Myzus persicae, as the majority of Cd accumulates in

62 leaf trichomes (Salt et al., 1995). We also carried out experiments to determine if females of either species could

63 differentiate between control and Cd-containing plants as a site for oviposition. Furthermore, we compared the

64 success of a parasitoid, Aphidius colmani, when provided M. persicae that were feeding on Cd-treated and control 65 plants.

66

67

68

69 Seeds of Brassica oleracea L. (var. Capitata 'Early Golden Acre') and B. juncea (L.) Czern. (cv. AC Vulcan) were obtained from Agriculture and Agri-Food Canada in London ON and Saskatoon SK, respectively. Seeds were

71 placed on top of wet filter paper in Petri plates, and germinated in the dark at room temperature. Once the radicles

72 were $>8 \mathrm{~mm}$ long, seedlings were transferred into individual pots filled with moistened, autoclaved Promix. All 73 plants were given distilled water daily, fertilized (20-20-20 all purpose fertilizer) once a week and kept at $60 \% \mathrm{RH}$, 74 with a 16:8 light:dark cycle and at $25: 20^{\circ} \mathrm{C}$ (day:night). Approximately 40 seeds were sown each week to provide a 75 continuous supply of plant material. Brassica oleracea were used solely for insect rearing while $B$. juncea received 76 one of three experimental treatments 3-4 weeks after sowing: one third received no $\mathrm{Cd}$ and served as control plants 77 (C; control), while the remaining plants were watered once with $\mathrm{CdCl}_{2}$ solutions to give 6 ( $\mathrm{LC}$; low cadmium) or 30 78 (HC; high cadmium) $\mathrm{mg} \mathrm{Cd} / \mathrm{kg}$ of soil, which resulted in $\mathrm{Cd}$ concentrations that are 0.5 and 2.4 times the limit for 79 agricultural soils, respectively (CCME, 2007). Furthermore, preliminary experiments found these soil concentrations 80 resulted in 3 and $10 \mathrm{mg} \mathrm{Cd} / \mathrm{kg}$ of leaf tissue, which caused sublethal effects in other herbivores (Quimby et al., 81 1979). Inflorescences were regularly removed, to ensure continued leaf production.

\section{Aphids and aphid parasitoids}

84 Ten green peach aphid adults from a laboratory colony were placed on five $B$. juncea plants from each of the three 85 plant treatments (see above) and allowed to larviposit for $24 \mathrm{~h}$. At this time the adults and additional neonates were 86 removed to leave a constant density of 10 neonate nymphs/plant. The survival of the nymphs and the time to reach 87 maturity (the production of nymphs) were determined. In addition, the proportion of individual nymphs that became 88 alate adults was recorded. 
Five plants from each of the treatment groups were infested with a mixture of adult and nymph green peach

90 aphids and placed in individual cages. Three mated 1-day-old Aphidius colemani females were introduced and

91 allowed to parasitize aphids for $24 \mathrm{~h}$. The parasitoids were removed and the plants examined daily for mummified

92 aphids. These were removed, and placed in individual gelatine capsules until adults emerged. The duration of larval

93 and pupal development, as well as the proportion of mummies that gave rise to adult parasitoids, were calculated.

\section{Cabbage loopers}

96 Insect colony - Eggs were obtained from Insect Production Services, Natural Resources Canada (NRCAN). Upon

97 hatching, cabbage looper larvae were reared individually on pinto bean diet (modified after Shorey and Hale, 1965)

98 in $29.6 \mathrm{~mL}$ cups and the adults obtained were used to establish a colony. Adults were kept in $3.7 \mathrm{~L}$ glass jars, the 99 openings of which were covered with cheese cloth to provide a substrate for egg laying. Sugar solution (8\%) was 100 provided for feeding. Eggs were surface-sterilized (10 min in 37\% formaldehyde, followed by 10 min rinse with 101 water), and newly hatched larvae were reared on either artificial diet (approx. $30 \mathrm{~mL}$ Solo cups) or on fresh $B$. 102 oleracea leaves (in Petri plates). These individuals were subsequently transferred to modified pinto bean artificial 103 diet or plants containing Cd. For all treatments, pupae were surface-sterilized in the same manner as the eggs, sexed 104 and weighed. Developmental times and mortality for each stage were recorded.

Oviposition - Fifteen newly emerged females were placed individually in cages with 2 males and once oviposition 107 was observed, females were transferred to mesh tents containing 8\% sugar solution and three $B$. juncea plants (one 108 each of C, LC and HC) for $48 \mathrm{~h}$. The plants were changed after $24 \mathrm{~h}$ allowing for determination of the total number 109 of eggs laid on treated and untreated plants during the two scotophases.

"No choice" feeding trails - Twenty $3^{\text {rd }}$ instar larvae were removed from their host plant (B. oleracea), starved for $24 \mathrm{~h}$ before the assay (to increase hunger levels), and placed in individual Petri dishes with either a control or Cdcontaining leaf disk of known area (measured using Image $\mathbf{J}$ software after pictures were taken). After $4 \mathrm{~h}$, pictures were taken, and the leaf surface area remaining was measured (Image $\mathbf{J}$ software) so that the area consumed and number of feeding sites could be calculated. 
Performance on artificial diet and B. juncea - Newly hatched neonates from the colony were allowed to feed on either artificial diet or fresh B. olaracea leaves for $24 \mathrm{~h}$ before being assigned to different experimental treatments.

119 There were six artificial diet treatments $(0,1,2,5,10$ and $20 \mathrm{mg} \mathrm{Cd} / \mathrm{kg}$ diet) with four replicates (25 larvae each).

120 There were three treatments for larvae reared on B. juncea host plants: C, LC, and HC soil treatments (25 larvae per treatment, repeated 5 times). Plants were replaced as they were defoliated. In both artificial diet and whole plant experiments, pupal mass, developmental times for both larvae and pupae were determined, and mortality was recorded daily.

\section{Cadmium content}

The concentrations of $\mathrm{Cd}$ in mature, control and Cd-treated B. juncea leaves, 5 larvae from the rearing colony and 5 larvae from each of control and Cd-treated B. juncea, as well as control and Cd-treated artificial diet were measured ( $\mathrm{n}=3$ for each treatment), using a modified United States Environmental Protection Agency (US EPA) test method SW-846 (US EPA, 2005). Oven-dried leaves and larvae were chopped into fine (1-2 mm) pieces using a razor blade while the dried diet was ground using a mortar and pestle. The three $0.1 \mathrm{~g}$ subsamples from each treatment were placed in individual $15 \mathrm{~mL}$ test tubes, $1 \mathrm{~mL}$ pure nitric acid (OmniTrace ${ }^{\circledR}$, EM Science, USA) was added to each one, and tubes were covered with a glass marble and left overnight at room temperature to begin digestion of organic matter. The following day, the samples were heated to $100^{\circ} \mathrm{C}$ on a hot plate until the vapors became transparent, then cooled to room temperature and filtered (VWR, qualitative grade 413) into $50 \mathrm{~mL}$ sterile centrifuge tubes. Reverse osmosis water was used to rinse the test tubes and bring the volume to $25 \mathrm{~mL}$. The samples were then analyzed for $\mathrm{Cd}$ content by inductivity-coupled plasma atomic emission spectrometry (ICP-AES). A certified standard reference material (SRM) from the National Institute of Standards and Technology (NIST 1573a, tomato leaves) and reagent blanks were used to assess accuracy of the sample digestion procedure for leaf and pinto bean diet. Digested SRM contained $92 \pm 3 \%$ of the certified amount of $\mathrm{Cd}$ and no $\mathrm{Cd}$ was detected in the reagent blanks. We did not assess the accuracy of the digestion procedure using an animal SRM for caterpillars, so it is possible that the values for Cd concentrations in looper larvae are underestimates. We did not measure $\mathrm{Cd}$ in aphids or parasitoids as this would have required $>400$ individuals per experimental replicate in each treatment to obtain $\mathrm{Cd}$ concentrations above the detection limit of the ICP-AES ( $0.002 \mu \mathrm{g} \mathrm{Cd} / \mathrm{ml}$ sample). 


\section{Statistical analysis}

Data were analysed using SPSS $^{\circledR}$ statistical software (Version 20.0) by one-way ANOVA followed by a Tukey’s post hoc test, and in cases where data were non-parametric, GraphPad Prism (Version 4.0) was used to perform a Kruskal-Wallis test followed by Dunn's multiple comparison. Due to some differences between sexes in the developmental times of $T . n i$ under the same concentrations of $\mathrm{Cd}$, data for males and females were analysed separately. Oviposition data were arcsine transformed to ensure normality and equality of variance.

\section{RESULTS}

Cd concentration Leaves from control B. juncea had $0.6 \pm 0.1 \mathrm{mg} \mathrm{Cd} / \mathrm{kg}$ dry weight, while those from the LC and HL treatments contained $3.2 \pm 0.6 \mathrm{mg} / \mathrm{kg}$, and $8.0 \pm 2.6 \mathrm{mg} / \mathrm{kg}$ dry weight, respectively. Larvae from the rearing colony had a dry weight Cd concentration of $0.4 \pm 0.2 \mathrm{mg} / \mathrm{kg}$, while those from the C, LC and HC plants had 1.3 \pm 0.4 , $5.5 \pm 1.0$, and $13.6 \pm 0.6 \mathrm{mg} / \mathrm{kg}$, respectively.

Aphids and parasitoids The number of aphids reaching maturation $(H=0.046, \mathrm{df}=2, P=0.98)$ and the age to the onset of reproduction $(H=0.298, \mathrm{df}=2, P=0.86)$, as well number of nymphs per reproductive female $(H=0.676$, $\mathrm{df}=2, P=0.71$ ), did not differ among the three Cd treatments (Table 1). Furthermore, none of the individuals reared on either control or treated plants were alates. There were no significant differences in the (i) number of mummies produced $(H=0.246, \mathrm{df}=2, P=0.88)$, (ii) times from parasitisation to mummification $(H=0.100, \mathrm{df}=$ 2, $P=0.95$ ) or from mummification to the emergence of adult parasitoids $(H=1.999, \mathrm{df}=2, P=0.37)$, or (iii) proportion of mummies giving rise to adult parasitoids $(H=1.220, \mathrm{df}=2, P=0.54)$ among the three $\mathrm{Cd}$ treatments (Table 1).

Cabbage loopers The total number of eggs laid by mated T. $n i$ females on control and Cd-containing plants did not $\operatorname{differ}\left(F_{(2,36)}=2.63, P=0.63\right)$. Furthermore, there were no differences in either the areas of the C, LC, and HC $B$. juncea leaves consumed $\left(F_{(2,87)}=0.377, P=0.69\right)$ or the number of feeding sites $\left(F_{(2,87)}=0.092, P=0.91\right)$ by $T$. $n i$ larvae in the no choice feeding trials. 
While the duration of larval development for both sexes was significantly shorter on HC plants than on controls (males: $F_{(2,168)}=7.77, \mathrm{p}<0.01$; females: $F_{(2,163)}=14.67, P<0.001$; Fig. 1a, b), pupal development time 175 did not differ among treatments for either males $(H=2.301, \mathrm{df}=2, P=0.32 \mathrm{Fig}$. 1a) or females $(H=5.801, \mathrm{df}=2$, $176 P=0.06$; Fig. 1b). Male pupal mass did not differ among treatments $(H=0.272, \mathrm{df}=2, P=0.99$; Fig. 1a), while 177 female pupae obtained from LC plants had approx. 10\% higher mass compared to those from $\mathrm{C}$ or HC plants $(H=$ $1787.130, \mathrm{df}=2, P<0.05$; Fig. 1b). The proportion of larvae pupating $\left(F_{(2,12)}=0.405, P=0.68\right)$ and pupae giving rise 179 to adults $\left(F_{(2,12)}=0.934, P=0.42\right)$ did not differ among treatments and controls (Fig. 2a). The developmental times of larvae $(H=137.6, \mathrm{df}=5, P<0.0001$ for males, and $H=95.66, \mathrm{df}=5, P<$

\section{DISCUSSION}

Cadmium is primarily found in the epidermis of leaf tissue, with very little or none in phloem (Masjasz-

Przybylowicz and Przybylowicz, 2011), thus a phloem-feeder, such as M. persicae, would ingest little Cd.

Furthermore, aphids can excrete excess amounts of some metals (e.g. copper) in honeydew (Crawford et al., 1995), while others may accumulate in certain body regions and associate with specific organs of sap-feeding insects (Merrington et al., 2001; Migula et al., 2007). Even if present, these metals do not necessarily have adverse effects on life history traits; Crawford et al. (1995) found no negative effects of Cd on Aphis fabae, similar to the results of our study with $M$. perscicae. Furthermore, we observed no alates (a winged form occurring when host plant quality is low) when the aphids were fed on Cd-containing plants. However, deviations from bilateral symmetry (Gorur, 2006), reduced reproductive potential and increased mortality (Gorur, 2007) were observed following accumulation of lead and copper in Brevicoryne brassicae. Thus, the impact on life history traits can vary depending on the metal 
and the species of sucking insect tested. If plants with high metal concentration are stressed, there might be beneficial effects for the metal-tolerant herbivore, as their performance may be enhanced when feeding on these stressed hosts (Koricheva et al., 1998). While some metals may be transferred up the food-chain (Vickerman and 204 Trumble, 2003), there is no evidence that this is the case for Cd (Zhang et al., 2009; Zhuang et al., 2009), which would explain the absence of differences in the performance of A. colemani . However, negative impacts due to synergistic effects of $\mathrm{Cd}$ with other compounds cannot be disregarded, as shown for $\mathrm{Cd}$ in combination with the insecticide imidacloprid on Aphidius ervi parasitoid (Kramarz and Stark, 2003).

The choice of oviposition sites by a female determines the fitness of her offspring, so females might avoid females can detect metals in oviposition sites have given inconsistent results. Drosophila melanogaster females can detect metals, and oviposit on substrates with concentrations that will enhance their offsprings' fitness (Bahadorani and Hilliker, 2009), while females of the cabbage white butterfly, Pieris rapae, avoid ovipositing on plants with 213 high concentrations of selenium (Freeman et al., 2006). In contrast, females of humpbacked fly, Megaselia scalaris 214 (Trumble and Jensen, 2004), and the beet armyworm, Spodoptera exigua (Vickerman et al., 2002), did not avoid 215 ovipositing on artificial diet or plants with toxic amounts of chromium (VI) or selenium, respectively, similar to $T$. $216 n i$ females in this study. The diversity of responses observed in the different studies could be due to significant 217 interspecific differences in the presence of appropriate sensillae to detect different metals or possibly, in the cases 218 where no responses were observed, the concentrations present in the substrate were below detectable limits for the 219 species tested.

Trichoplusia ni larvae developed at a similar rate, and had similar performance on Cd-containing versus control plants, indicating that they either do not have sensillae that detect this metal, or that the concentrations present in the contaminated plants were not sufficiently high to modify their feeding behavior. Furthermore, there was no evidence of post-ingestion associative learning (Hanson et al., 2003; Behmer et al., 2005), often observed in feeding trial experiments where the consumption of metal-containing foliage has a negative effect on the growth and development of the herbivore. The only significant difference observed was a 1-2 day shorter larval developmental time for both sexes in the high Cd treatment, without a subsequent reduction in either pupal mass or adult emergence. In fact female pupae were bigger on LC plants. These changes may be more accentuated under fluctuating temperature conditions in the field and could actually benefit the herbivore, as a shorter larval period 
could reduce the exposure time to natural enemies attacking caterpillars (Dmitriew and Rowe, 2005; Muller and Arand, 2007), while larger pupal mass may result in higher fecundity (Gilbert, 1984; Honek et al., 2008). The better performance on low Cd plants is consistent with hormesis, a widely occurring toxicological phenomenon where low doses of a known toxin may actually be favourable (Calabrese and Blain, 2005), demonstrated in Phormia regina exposed to Cd (Nascarella et al., 2003). Furthermore, Cd can replace calcium in protein kinase C (Kiss and

Osipenko, 1994), but can also be retained by cell lysosomes (Johnson and Foulkers, 1980; Lauverjat et al., 1989), which could explain no negative effect at low doses of $\mathrm{Cd}$.

When T. $n i$ larvae were reared on artificial diet the most detrimental effects were observed in the 2 and 20 $\mathrm{mg} / \mathrm{kg}$ treatments where not only was mortality high, but larval and pupal development times were longer.

Therefore, it is possible that surviving individuals in these two treatments could have a greater probability of being attacked by natural enemies during larval development (but not during the pupal stage for while statistical differences were detected they were small and probably of little biological importance), and lower reproductive success as adults. These findings are consistent with other studies showing growth and development were negatively affected by Cd exposure in Lymantria dispar (Gintenveiter et al., 1993; Ilijin et al., 2010; Mircic et al., 2010), and by sewage sludge in $T . n i$ (Larsen et al., 1994). Possible causes of insects' lower performance are reduced efficacy in obtaining nutrients, as the digestibility of plant material is reduced by the presence of Cd (Van Ooik et al., 2007), and disruption of metabolic processes (Janssens et al., 2009), as Cd affects protocerebral neurosecretory neurones (Ilijin et al., 2010) that affect growth and development. Additionally, metals can act as immunotoxins, affecting haemocyte morphology, which under natural conditions could result in increased probability of infections and attack by parasitoids (Borowska and Pyza, 2011), although this is not always the case (Popham et al., 2005).

We currently have no explanation for the absence of a normal dose-dependent response, with increasingly adverse effects with increasing Cd concentrations in the diet. However, we do believe the pattern is real as the same results were obtained in each of the four replicates. It should also be noted that in a study looking at Cd tolerance in two species of Brassica, using a hydroponic system, the observed reduction in root and stem dry mass was greater at low than medium doses of cadmium, when compared with controls (Gadapati and Macfie, 2006). Clearly, additional research is necessary to clarify this situation. However, the somewhat different findings obtained from the two sets of experiments (whole plants and artificial diet) suggest that caution should be taken when extrapolating the data from diets treated with metals to whole plants. Interestingly, the concentration of Cd in the $2 \mathrm{mg} / \mathrm{kg}$ diet was lower 
257 than the levels of $\mathrm{Cd}$ found in $\mathrm{LC}$ and $\mathrm{HC}$ plants, where possible hormesis was observed. It is also possible that the 258 presence of secondary plant compounds, such as isothiocyanates, in whole plants affect the uptake of Cd by 259 herbivores, a possibility that merits further investigation. 
BAHADORANI, S. and HILLIKER, A. J. 2009. Biological and behavioral effects of heavy metals in Drosophila melanogaster adults and larvae. J. Insect Behav. 22:399.

BEHMER, S., LLOYD, C., RAUBENHEIMER, D., STEWART-CLARK, J., KNIGHT, J., LEIGHTON, R., HARPER, F., and SMITH, J. 2005. Metal hyperaccumulation in plants: Mechanisms of defence against insect herbivores. Funct. Ecol. 19:55.

BOROWSKA, J. and PYZA, E. 2011. Effects of heavy metals on insect immunocompetent cells. J. Insect Physiol. 57:760.

BOYD, R. 2004. Ecology of metal hyperaccumulation. New Phytol. 162:563.

BRESLIN, V. 1999. Retention of metals in agricultural soils after amending with MSW and MSW-biosolids compost. Water Air and Soil Pollution 109:163.

BUTLER, C. D. and TRUMBLE, J. T. 2008. Effects of pollutants on bottom-up and top-down processes in insectplant interactions. Environmental Pollution 156:1.

CALABRESE, E. and BLAIN, R. 2005. The occurrence of hormetic dose responses in the toxicological literature, the hormesis database: An overview. Toxicol. Appl. Pharmacol. 202:289.

CANADIAN COUNCIL OF MINISTERS OF THE ENVIRONMENT (CCME). 2007. Canadian soil quality guidelines for the protection of environmental and human health www.ceqg-rcqe.ccme.ca (accessed Jan 13, 2013).

CHANEY, R., MALIK, M., LI, Y., BROWN, S., BREWER, E., ANGLE, J., and BAKER, A. 1997. Phytoremediation of soil metals. Curr. Opin. Biotechnol. 8:279.

CRAWFORD, L., HODKINSON, I., and LEPP, N. 1995. The effects of elevated host-plant cadmium and copper on the performance of the aphid Aphis fabae (Homoptera: Aphididae). J. Appl. Ecol. 32:528.

CUI, Y., FU, J., and CHEN, X. 2011. Speciation and bioaccessibility of lead and cadmium in soil treated with metal-enriched Indian mustard leaves. Journal of Environmental Sciences-China 23:624.

CUNNINGHAM, S., SHANN, J., CROWLEY, D., and ANDERSON, T. 1997. Phytoremediation of contaminated water and soil. Phytoremediation of Soil and Water Contaminants 664:2.

DMITRIEW, C. and ROWE, L. 2005. Resource limitation, predation risk and compensatory growth in a damselfly. Oecologia 142:150.

FILSER, J., WITTMANN, R., and LANG, A. 2000. Response types in collembola towards copper in the microenvironment. Environmental Pollution 107:71.

FREEMAN, J. L., QUINN, C. F., MARCUS, M. A., FAKRA, S., and PILON-SMITS, E. A. H. 2006. Seleniumtolerant diamondback moth disarms hyperaccumulator plant defense. Current Biology 16:2181.

GADAPATI, W. R. and MACFIE, S. M. 2006. The production of phytochelatins is only partially correlated with reduced Cd-stress in two species of Brassica. Plant Science 170:471.

GILBERT, N. 1984. Control of fecundity in Pieris rapae .1. The problem. J. Anim. Ecol. 53:581.

GINTENREITER, S., ORTEL, J., and NOPP, H. 1993. Effects of different dietary levels of cadmium, lead, copper, and zinc on the vitality of the forest pest insect Lymantria dispar L (Lymantriidae, Lepidoptera). Arch. Environ. Contam. Toxicol. 25:62.

GORUR, G. 2006. Developmental instability in cabbage aphid (Brevicoryne brassicae) populations exposed to heavy metal accumulated host plants. Ecol. Indic. 6:743.

GORUR, G. 2007. Effects of host plant contaminated with heavy metals on the life history traits of aphids (brevicoryne brassicae L.). Pol. J. Ecol. 55:113.

HANSON, B., GARIFULLINA, G., LINDBLOM, S., WANGELINE, A., ACKLEY, A., KRAMER, K., NORTON, A., LAWRENCE, C., and PILON-SMITS, E. 2003. Selenium accumulation protects Brassica juncea from invertebrate herbivory and fungal infection. New Phytol. 159:461.

HONEK, A., DIXON, A. F. G., and MARTINKOVA, Z. 2008. Body size, reproductive allocation, and maximum reproductive rate of two species of aphidophagous Coccinellidae exploiting the same resource. Entomol. Exp. Appl. 127:1.

ILIJIN, L., PERIC-MATARUGA, V., RADOJICIC, R., LAZAREVIC, J., NENADOVIC, V., VLAHOVIC, M., and MRDAKOVIC, M. 2010. Effects of cadmium on protocerebral neurosecretory neurons and fitness components in Lymantria dispar L. Folia Biologica-Krakow 58:91.

JAHANGIR, M., ABDEL-FARID, I. B., CHOI, Y. H., and VERPOORTE, R. 2008. Metal ion-inducing metabolite accumulation in Brassica rapa. J. Plant Physiol. 165:1429.

JANSSENS, T. K. S., ROELOFS, D., and VAN STRAALEN, N. M. 2009. Molecular mechanisms of heavy metal tolerance and evolution in invertebrates. Insect Science 16:3. 
JOHNSON, D. and FOULKERS, E. 1980. On the proposed role of metallothionein in the transport of cadmium. Environ. Res. 21:360.

KISS, T. and OSIPENKO, O. 1994. Toxic effects of heavy-metals on ionic channels. Pharmacol. Rev. 46:245.

KORICHEVA, J., LARSSON, S., and HAUKIOJA, E. 1998. Insect performance on experimentally stressed woody plants: A meta-analysis. Annu. Rev. Entomol. 43:195.

KRAMARZ, P. and STARK, J. 2003. Population level effects of cadmium and the insecticide imidacloprid to the parasitoid, Aphidius ervi after exposure through its host, the pea aphid, Acyrthosiphon pisum (Harris). Biological Control 27:310.

KUMAR, P., DUSHENKOV, V., MOTTO, H., and RASKIN, I. 1995. Phytoextraction - the use of plants to remove heavy-metals from soils. Environ. Sci. Technol. 29:1232.

LARSEN, K., LITSCH, A., BREWER, S., and TAYLOR, D. 1994. Contrasting effects of sewage-sludge and commercial fertilizer on egg to adult development of 2 herbivorous insect species. Ecotoxicology 3:94.

LAUVERJAT, S., BALLAN-DUFERANCAIS, C., and WEGNEZ, M. 1989. Detoxification of cadmium. Ultrastructural study and electron-probe microanalysis of the midgut in cadmium- resistantstrain Drosophila melanogaster. Biology of Metals 2:97.

MERRINGTON, G., MILLER, D., MCLAUGHLIN, M., and KELLER, M. 2001. Trophic barriers to fertilizer Cd bioaccumulation through the food chain: A case study using a plant-insect predator pathway. Arch. Environ. Contam. Toxicol. 41:151.

MESJASZ-PRZYBYLOWICZ, J. and PRZYBYLOWICZ, W. J. 2011. PIXE and metal hyperaccumulation: From soil to plants and insects. X-Ray Spectrom. 40:181.

MIGULA, P., PRZYBYLOWICZ, W. J., MESJASZ-PRZYBYLOWICZ, J., AUGUSTYNIAK, M., NAKONIECZNY, M., GLOWACKA, E., and TARNAWSKA, M. 2007. Micro-PIXE studies of elemental distribution in sap-feeding insects associated with Ni hyperaccumulator, Berkheya coddii. Plant Soil 293:197.

MIRCIC, D., JANKOVIC-TOMANIC, M., NENADOVIC, V., FRANETA, F., and LAZAREVIC, J. 2010. The effects of cadmium on the life history traits of Lymantria dispar L. Archives of Biological Sciences 62:1013.

MOGREN, C. L. and TRUMBLE, J. T. 2010. The impacts of metals and metalloids on insect behavior. Entomol. Exp. Appl. 135:1.

MULLER, C. and ARAND, K. 2007. Trade-offs in oviposition choice? Food-dependent performance and defence against predators of a herbivorous sawfly. Entomol. Exp. Appl. 124:153.

NASCARELLA, M., STOFFOLANO, J., STANEK, E., KOSTECKI, P., and CALABRESE, E. 2003. Hormesis and stage specific toxicity induced by cadmium in an insect model, the queen blowfly, Phormia regina Meig. Environmental Pollution 124:257.

NORDBERG, G. F. 2009. Historical perspectives on cadmium toxicology. Toxicol. Appl. Pharmacol. 238:192.

PRASAD, M. 1995. Cadmium toxicity and tolerance in vascular plants. Environ. Exp. Bot. 35:525.

POPHAM H. J. R., SHELBY, K. S., and POPHAM, T. W. 2005 Effect of dietary selenium supplementation on resistance to baculovirus infection. Biol. Control 32:419.

QUIMBY, P., FRICK, K., WAUCHOPE, R., and KAY, S. 1979. Effects of cadmium on 2 biocontrol insects and their host weeds. Bull. Environ. Contam. Toxicol. 22:371.

SALT, D.E.,PRINCE, R.C., PICKERING, I.J., and RASKIN, I. 1995.Mechanisms of cadmium mobility and accumulation in Indian mustard. Plant Physiol. 109: 1427.

SHOREY, H., and HALE, R. 1965. Mass-rearing of the larvae of nine noctuid species on a simple artificial medium. J. Econ. Entomol. 58: 522.

TRUMBLE, J. and JENSEN, P. 2004. Ovipositional response, developmental effects and toxicity of hexavalent chromium to Megaselia scalaris, a terrestrial detritivore. Arch. Environ. Contam. Toxicol. 46:372.

US EPA (United States Environmental Protection Agency), 2005. Test methods for evaluating solid waste, physical/chemical methods, series 3000. [Online] Available: http://www.epa.gov/epaoswer/hazwaste/test/main.htm/ (accessed Jan 20, 2012)

VAN OOIK, T., RANTALA, M. J., and SALONIEMI, I. 2007. Diet-mediated effects of heavy metal pollution on growth and immune response in the geometrid moth Epirrita autumnata. Environmental Pollution 145:348.

VICKERMAN, D., YOUNG, J., and TRUMBLE, J. 2002. Effect of selenium-treated alfalfa on development, survival, feeding, and oviposition preferences of Spodoptera exigua (Lepidoptera: Noctuidae). Environ. Entomol. 31:953.

VICKERMAN, D., and TRUMBLE, J. 2003. Biotransfer of selenium: effects on the insect predator, Podisus maculiventris, Ecotoxicology 12:497. 
ZHANG, Z., LU, X., WANG, Q., and ZHENG, D. 2009. Mercury, cadmium and lead biogeochemistry in the soilplant-insect system in Huludao city. Bull. Environ. Contam. Toxicol. 83:255.

ZHUANG PING, ZOU HUILING, and SHU WENSHENG. 2009. Biotransfer of heavy metals along a soil-plantinsect-chicken food chain: Field study. Journal of Environmental Sciences-China 21:849. 
Table 1 MEAN ( \pm SE) PERCENT OF REPRODUCING FEMALES, AGE TO REPRODUCTION, AND NUMBER OF NYMPHS PER REPRODUCTIVE FEMALE OF Myzus percicae AS WELL AS MEAN ( \pm SE) NUMBER OF MUMMIES, PERCENT MUMMIES EMERGING, TIME TO MUMMIFICATION, AND TIME TO ADULT OF Aphidius colemani

Note: Means followed by the same letter within each column are not significantly different based on Kruskal- Wallis analysis $(\alpha=0.05)$.

Figure 1 Mean ( \pm SE) pupal mass, larval, and development of Trichoplusia ni males (A) and females (B) after feeding on Cd-containing B. juncea plants. $\mathrm{C}=$ control, $\mathrm{LC}=$ low $\mathrm{Cd}, \mathrm{HC}=$ high $\mathrm{Cd}$. Bars with the same letter are not significantly different based on Tukey's post hoc test $(\mathrm{p}<0.05)$ and Dunn's multiple comparison test $(\mathrm{p}<0.05)$.

468 Figure 2 Mean $( \pm \mathrm{SE})$ proportion of $T$. $n i$ individuals reaching pupal (p) and adult (a) stages after feeding on Cd469 containing B. juncea plants (A) and Cd-containing artificial diet (B). C= control, $\mathrm{LC}=$ low $\mathrm{Cd}, \mathrm{HC}=$ high $\mathrm{Cd}$. Bars 470 with the same letter are not significantly different based on Dunn's multiple comparison test $(\mathrm{p}<0.05)$.

Figure 3 Mean ( \pm SE) pupal mass, larval, and pupal development of Trichoplusia ni males (A) and females (B) after feeding on Cd-containing artificial diet. Cadmium concentrations are in $\mathrm{mg} / \mathrm{kg}$ diet. Bars with the same letter are not significantly different based on Tukey's post hoc test $(\mathrm{p}<0.05)$ and Dunn's multiple comparison test $(\mathrm{p}<0.05)$. 

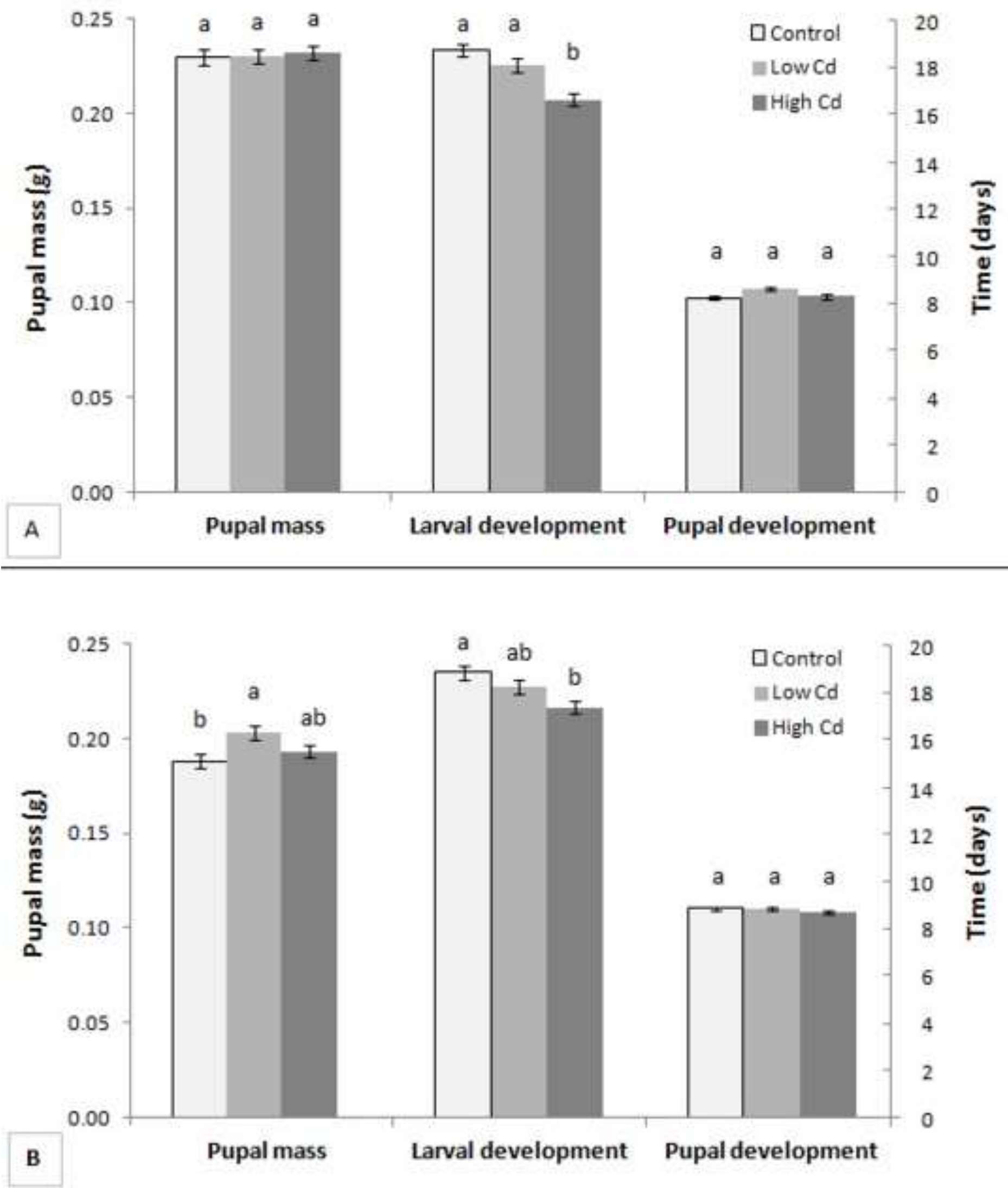

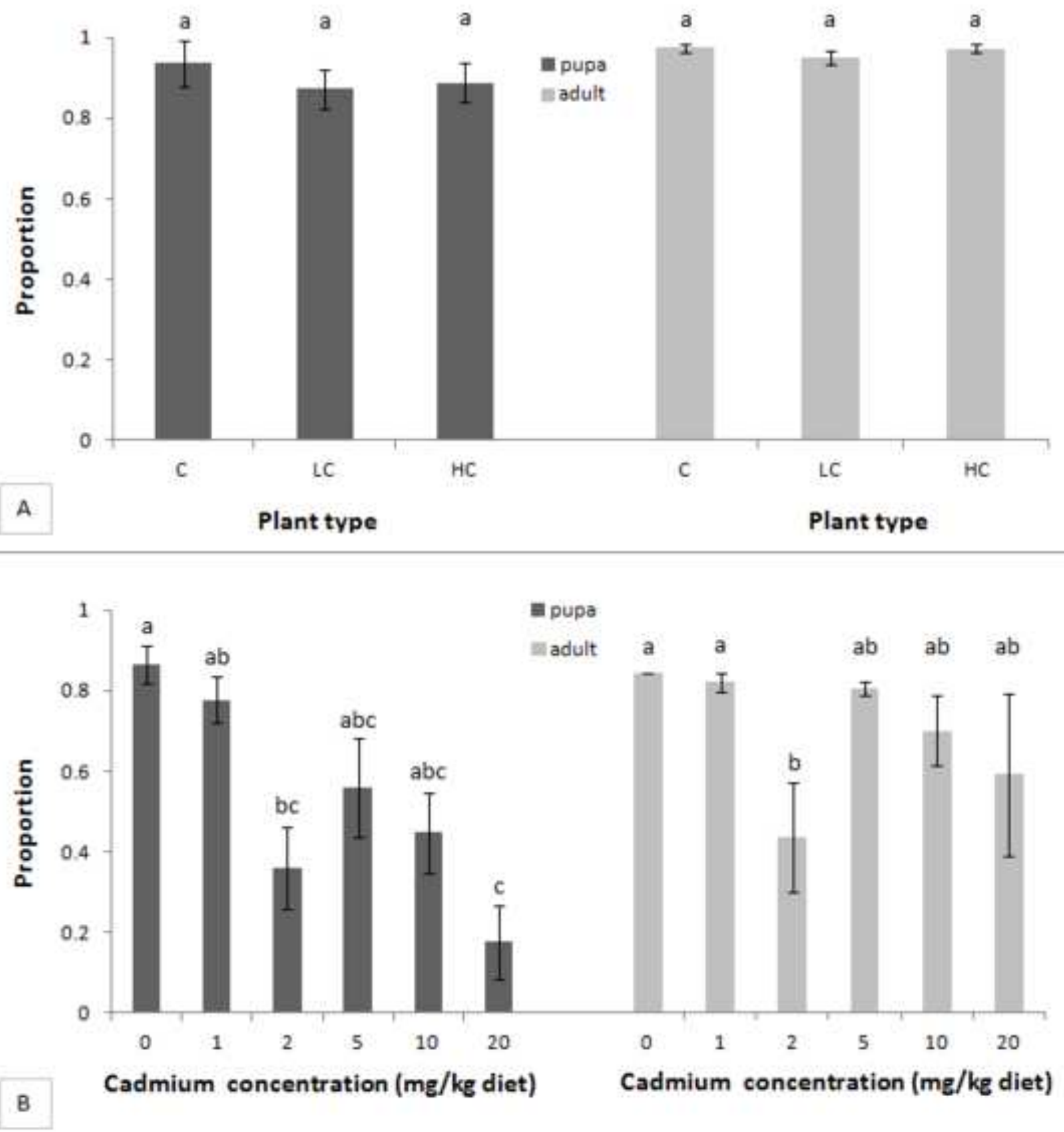


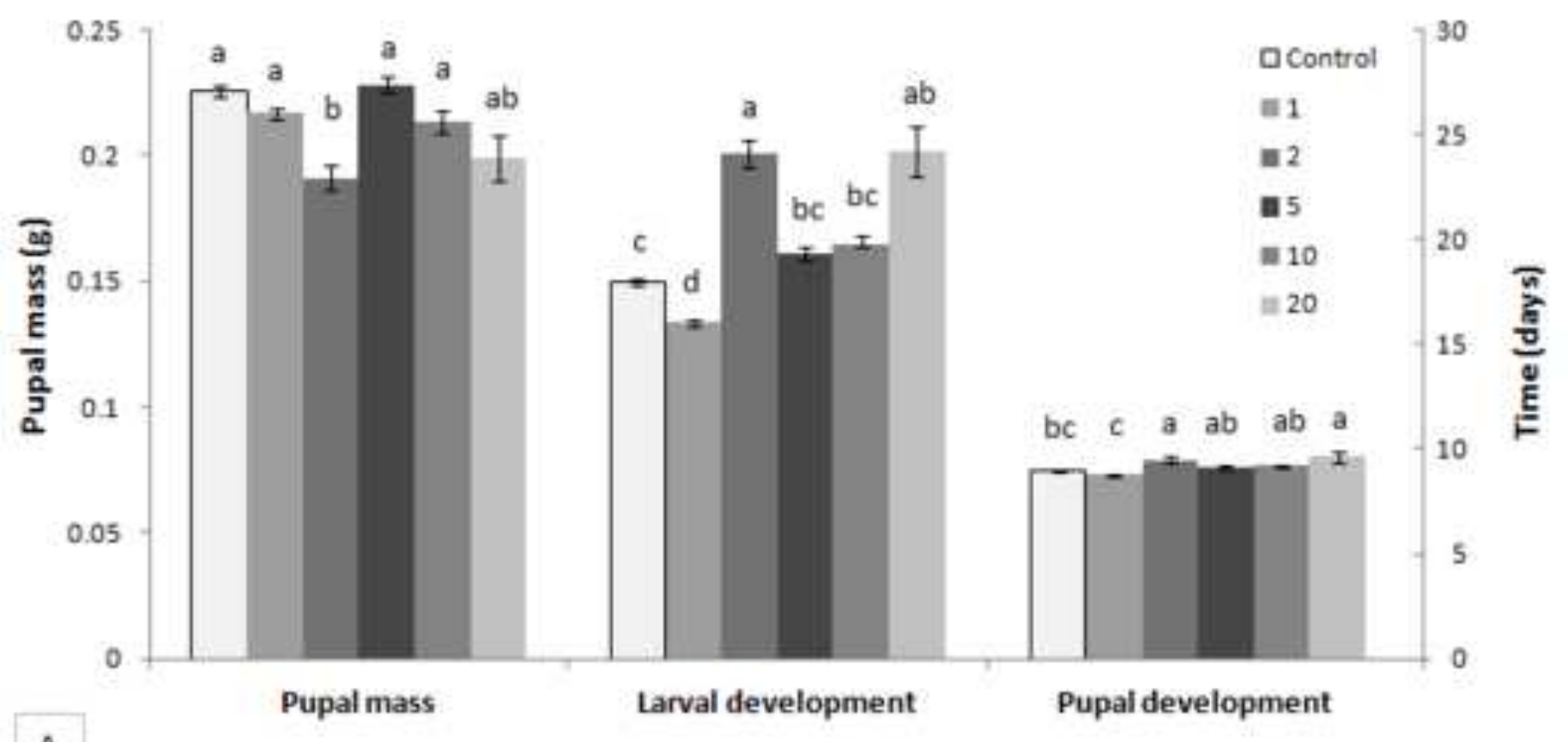

A

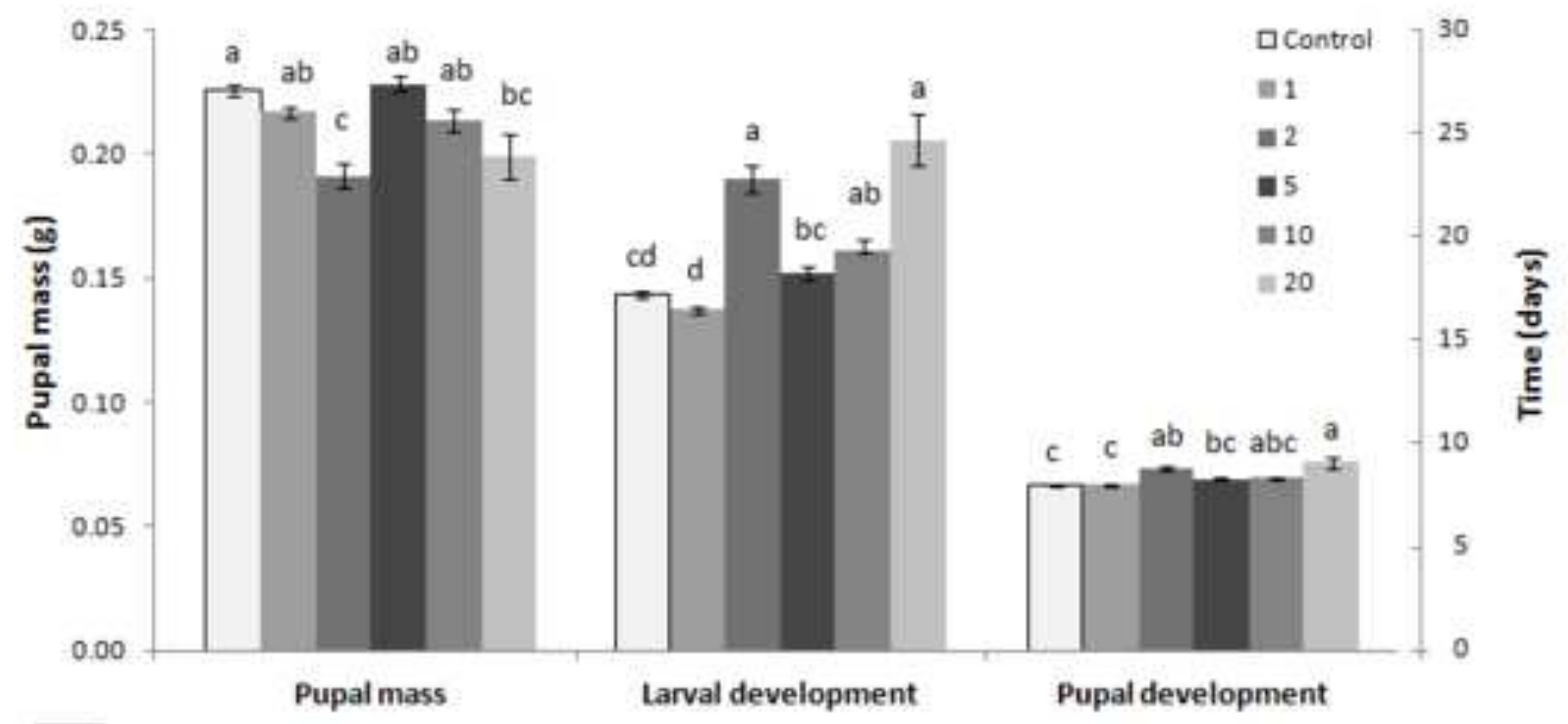

B 


\begin{tabular}{cccccccc}
\hline Aphids & \multicolumn{7}{c}{ Parasitoids } \\
\hline & $\begin{array}{c}\text { Reproducing } \\
\text { females (\%) }\end{array}$ & $\begin{array}{c}\text { Age to } \\
\text { reproduction }\end{array}$ & $\begin{array}{c}\text { Nymphs per } \\
\text { reproductive female }\end{array}$ & $\begin{array}{c}\text { Number of } \\
\text { mummies }\end{array}$ & \% emerging & $\begin{array}{c}\text { Time to } \\
\text { mummification }\end{array}$ & Time to adult \\
Control & $64.0 \pm 10.3 \mathrm{a}$ & $8.0 \pm 0.4 \mathrm{a}$ & $2.52 \pm 0.4 \mathrm{a}$ & $52.0 \pm 12.1 \mathrm{a}$ & $38.7 \pm 2.3 \mathrm{a}$ & $8.0 \pm 0.1 \mathrm{a}$ & $12.4 \pm 0.1 \mathrm{a}$ \\
LC & $60.0 \pm 20.5 \mathrm{a}$ & $8.2 \pm 0.3 \mathrm{a}$ & $2.14 \pm 0.6 \mathrm{a}$ & $57.6 \pm 11.7 \mathrm{a}$ & $40.1 \pm 1.6 \mathrm{a}$ & $8.0 \pm 0.1 \mathrm{a}$ & $12.6 \pm 0.1 \mathrm{a}$ \\
HC & $62.0 \pm 18.3 \mathrm{a}$ & $8.3 \pm 0.4 \mathrm{a}$ & $2.12 \pm 0.6 \mathrm{a}$ & $60.0 \pm 11.2 \mathrm{a}$ & $39.2 \pm 1.3 \mathrm{a}$ & $8.0 \pm 0.1 \mathrm{a}$ & $12.5 \pm 0.1 \mathrm{a}$ \\
\hline
\end{tabular}

